\title{
Preparation of Tamarind Jam Blended with Mango
}

\author{
E. Kiranmai*, A. Suneetha and Nikita Sethi \\ Indian Institute of Millets Research, Rajendranagar, Hyderabad, Telangana, India \\ *Corresponding author
}

\section{A B S T R A C T}

Keywords

Tamarind, Mango, Jam, Sensory

attributes and storage.

Article Info

Accepted:

26 October 2017

Available Online:

10 December 2017
A study was conducted to evaluate the physico-chemical, sensory quality characteristics and storage stability of the developed products prepared with tamarind by blending with mango pulp. Tamarind pulp was used for the preparation of jam by blending with different levels (10\%, 20\%, 30\%, $40 \%$ and $50 \%$ ) of mango pulp. These prepared products were evaluated for Physico-chemical, sensory and microbial attributes during the storage period at room temperature. The overall acceptability was the highest in jam prepared with $60 \%$ tamarind pulp $+40 \%$ mango pulp $\left(\mathrm{T}_{5}\right)$, and stored without any deterioration and consumer acceptable up to 3 months without affecting their quality.

\section{Introduction}

Tamarind is native fruit of Africa. It belongs to Leguminosae family with botanical name Tamarindus indica. L. It is one of the important tropical fruit tree, and is widely grows in India. It yields $150-500 \mathrm{Kg}$ fruits per season and the fruit weight vary from $15-30$ gms (Duke, 1981). Utilization of these fruits for preparation of various processed products are limited. Tamarind also has hypoglycemic and hypocholestrolemic effect and it helps in reducing obesity (www.tamarindmanual. htm). Blending of fruits like mango will be helpful to enhance the sensory quality characteristics such as color, flavour, taste, and overall acceptability of the prepared products. Keeping the above facts in view an experiment was planned for better utilization of tamarind.

\section{Materials and Methods}

Red variety tamarind was procured from local market and seeds were removed and the tamarind was cleaned properly. Then the tamarind was soaked in water in the 1: 1.5 ratio, heated up to $100^{\circ} \mathrm{C}$, then cooled and crushed. After crushing it was passed through a siever to obtain pulp. The pulp so obtained was used for the preparation of products. The flow diagram for extraction of tamarind pulp was given in (Fig. 1). Mangoes also procured from local market and cleaned properly.

\section{Preparation of tamarind jam}

Tamarind pulp was used for the preparation of jam by blending with different levels $(10 \%$, $20 \%, 30 \%, 40 \%$ and $50 \%$ ) of mango pulp. Extracted pulp was mixed with sufficient 
quantity of sugar and boiled. Boiling was continued till the required consistency was obtained. While boiling pectin was added. The flow diagram depicting preparation of jam was given in (Fig. 2).

\section{Physico-chemical parameters of developed tamarind jam}

Prepared products were analyses at monthly intervals for the following parameters Except Sensory evaluation ( 0 days, 45 days and 90 days).

\section{Moisture (\%)}

The moisture content of the samples was determined by using the method of AOAC (1975).

\section{Total soluble solids ( $\left.{ }^{0} \mathrm{Brix}\right)$}

The percentage of total soluble solids was determined using ERMA hand refractometer by placing a drop of the filtered juice on the refractometer prism. Before taking the reading, the refractometer was tested for error with distilled water (Ranganna, 1986).

\section{Acidity (\%)}

Ten grams of homogenized sample was taken and made up to $100-\mathrm{ml}$. volume in a volumetric flask. The contents were than filtered through Whatman No.1 filter paper; an aliquot of $1 \mathrm{ml}$. was taken for titration against $0.1 \mathrm{~N} \mathrm{NaOH}$ using phenolphthalein indicator and light pink colour as end point, to estimate titrable acidity in terms of tartaric acid (AOAC, 1975).

\section{Reducing sugars (\%)}

Reducing sugars were determined by the method of Lane and Eyon (AOAC, 1975). Ten grams of samples was transferred to 250 ml volumetric flask using a little amount of distilled water. $2 \mathrm{ml}$ of lead acetate. Solution was added to the flask for precipitation of colloidal matter and kept aside for $10 \mathrm{~min}$. Then $2 \mathrm{ml}$ of potassium oxalate solution was added to this solution to precipitate the lead and then the volume was made up to $250 \mathrm{ml}$ using distilled water. And the contents were then filtered through Whatman no.1 filter paper. Reducing sugars in the lead free solution were then estimated by taking this solution in burette and titrating against $10 \mathrm{ml}$ of standard Fehling's solution mix of A and B (1:1), using methylene blue as an indicator and formation of brick red precipitate as an end point. Keeping the Fehling's solution boiling on the heating mantle carried out the titration.

\section{Total sugars $(\%)$}

For total sugars, $50 \mathrm{ml}$ of filtered sample was taken in a $250 \mathrm{ml}$ conical flask to which $50 \mathrm{ml}$ water and $5 \mathrm{gm}$ of citric acid was added boiled gently for 10 mints to complete the inversion of sucrose, then transferred to 250 $\mathrm{ml}$ volumetric flask and neutralized with $1 \mathrm{~N}$ $\mathrm{NaOH}$. The volume was made up to the mark and determined the total sugar as invert sugars (AOAC, 1975).

\section{Sensory evaluation (Peryam et al., 1957)}

The sensory scoring was done by a panel of 10 members in the laboratory of Post Graduate and Research center using a scorecard developed for the purpose. Scorecard was prepared keeping in view of the quality characteristics of the products. Descriptive terms were given to various quality attributes like appearance, colour, flavour, texture, consistency, taste and overall acceptability. Numerical scores were assigned to each attribute (Peryam and pilgrim, 1959). A five-point scale was adopted to score each of the attributes, while scoring, highest score 
(5) was assigned to most preferred characteristic and least score (1) to the least desired characteristics.

\section{Total bacterial counts (Cruikshank et al., 1975)}

For estimating bacterial population in different samples, dilution plate method was followed (Cruikshank et al., 1975). One gram of sample was thoroughly mixed in $9 \mathrm{ml}$ of sterile saline water, from this, $1 \mathrm{ml}$ of sample was transferred through a sterile pipette to a screw cap tube containing $9 \mathrm{ml}$ sterile saline water, and this gives a dilution of $10^{2}$. Similarly, serial dilutions were made.

One ml. of the sterile serially dilute of sample was placed in the sterile petridish to which cooled plate count agar medium was added and mixed thoroughly with the suspension and then allowed to set and then incubated at $28+2^{0} \mathrm{C}$ for $48 \mathrm{hrs}$.

Individual colonies were counted and multiplied. Dilution plate method was followed for yeast and mold content (Cruikshank et al., 1975). Potato dextrose agar medium was used for estimating the fungal population.

\section{Statistical analysis}

The data were subjected to statistical analysis as per the procedure described by Panse and Sukhatme (1985). The experimental design was complete randomized design with factorial concept.

\section{Results and Discussion}

Prepared products were analyzed for physico chemical parameters Moisture, TSS, Acidity, Reducing sugars, Total sugars, sensory and microbial characteristics. The results were shown in the Table 1 to 6 and Figure 4.

\section{Physico-chemical parameters of tamarind} jam

\section{Moisture (\%)}

A significant decrease at $1 \%$ level in moisture was observed (Table 1) after 90 days of storage. Tripathi et al., (1988) in jam prepared with amla products and Jain et al., (1983) reported similar observations.

\section{Total soluble solids (Brix)}

The total soluble solids (TSS) in tamarind jam (Table 2), though varied among the different treatments due to initial adjustment of higher Brix values, remained practically unchanged during storage.

During 30-90 days of storage, a very slight increase in T.S.S was observed, which remained statistically non-significant. These results were in accordance with the results reported by Jadhav et al., (2004) in karonda jam, Koli et al., (2004) in sapota jam and Tripathi et al., (1988) in amla jam. This may be due to the concentration effect as the products lost moisture during storage (Tripathi et al., 1988). The increase in TSS content may also be due to conversion of polysaccharides into sugars (Singh et al., 2004).

\section{Acidity (\%)}

During storage, there was practically no change in acidity of tamarind jam (table 3) stored at room temperature up to three months of storage. Similar reports were observed by Salvi (1991) in karonda products. Though, there was a slight decrease in acidity from 60 days to 90 days of storage, it remained statistically non-significant. Similar findings in jamun fruit products Garande and Joshi (1995) and in karonda fruit products (Jadhav et al., 2004) were reported. 
Table.1 Effect of storage period on moisture (\%) in tamarind jam at room temperature

\begin{tabular}{cccccc}
\hline TREATMENTS & $\mathbf{0}$ & $\mathbf{3 0}$ & Moisture (\%) & $\mathbf{6 0}$ & Mean \\
$\mathrm{T}_{1}$ & 68.40 & 68.02 & 68.01 & 68.01 & 68.11 \\
$\mathrm{~T}_{2}$ & 68.39 & 68.02 & 68.01 & 68.01 & 68.108 \\
$\mathrm{~T}_{3}$ & 68.42 & 68.06 & 68.02 & 68.02 & 68.01 \\
$\mathrm{~T}_{4}$ & 68.37 & 68.08 & 68.02 & 68.02 & 68.123 \\
$\mathrm{~T}_{5}$ & 68.35 & 68.1 & 68.02 & 68.02 & 68.123 \\
$\mathrm{~T}_{6}$ & 68.40 & 68.12 & 68.02 & 68.02 & 68.14 \\
Mean & 68.388 & 68.067 & 68.017 & 68.017 & \\
& & $\mathbf{F ~ v a l u e}$ & $\mathbf{S E d} \pm$ & $\mathbf{C D}$ at 5\% & \\
Treatments $\left(\mathbf{F}_{\mathbf{1}}\right)$ & & $* *$ & 1.78 & 2.309 & \\
Periods $\left(\mathbf{F}_{\mathbf{2}}\right)$ & & $* *$ & 1.443 & 2.828 & \\
$\mathbf{F}_{\mathbf{1}} * \mathbf{F}_{\mathbf{2}}$ Interaction & & $* *$ & 2.886 & 5.656 & \\
\hline
\end{tabular}

Where, $\mathrm{T}_{1}$ : tamarind pulp $100 \%, \mathrm{~T}_{2}$ : tamarind pulp 90\%+mango pulp10\%, $\mathrm{T}_{3}$ : tamarind pulp $80 \%+$ mango pulp $20 \%, \mathrm{~T}_{4}$ : tamarind pulp 70\%+mango pulp 30\%, $\mathrm{T}_{5}$ : tamarind pulp 60\%+mango pulp 40\%, $\mathrm{T}_{6}$ : tamarind pulp $50 \%+$ +mango pulp $50 \%$. * significant at $1 \%$ level, NS- non significant.

Table.2 Effect of storage period on T.S.S ( ${ }^{0}$ Brix) in tamarind jam at room temperature

\begin{tabular}{cccccc}
\hline & & & T.S.S ( $\left.{ }^{\mathbf{0} B r i x}\right)$ & \\
TREATMENTS & $\mathbf{0}$ & $\mathbf{3 0}$ & $\mathbf{6 0}$ & $\mathbf{9 0}$ & Mean \\
$\mathrm{T}_{1}$ & 65.00 & 65.00 & 65.33 & 65.35 & 65.162 \\
$\mathrm{~T}_{2}$ & 65.00 & 65.00 & 65.31 & 65.34 & 65.150 \\
$\mathrm{~T}_{3}$ & 65.00 & 65.00 & 65.34 & 65.36 & 65.134 \\
$\mathrm{~T}_{4}$ & 68.00 & 68.00 & 68.32 & 68.33 & 68.160 \\
$\mathrm{~T}_{5}$ & 68.00 & 68.00 & 68.30 & 68.32 & 68.158 \\
$\mathrm{~T}_{6}$ & 68.00 & 68.00 & 68.32 & 68.33 & 68.165 \\
Mean & 66.50 & 66.50 & 66.80 & 66.83 & \\
& & $\mathbf{F ~ v a l u e}$ & $\mathbf{S E d} \pm$ & $\mathbf{C D}$ at 5\% & \\
Treatments $\left(\mathbf{F}_{\mathbf{1}}\right)$ & & $* *$ & 0.0992 & 0.01987 & \\
Periods $\left(\mathbf{F}_{\mathbf{2}}\right)$ & & $\mathrm{NS}$ & 0.0701 & $\mathrm{NS}$ & \\
$\mathbf{F}_{\mathbf{1}} * \mathbf{F}_{\mathbf{2}}$ Interaction & & $\mathrm{NS}$ & 0.01718 & $\mathrm{NS}$ & \\
\hline
\end{tabular}

Where, $\mathrm{T}_{1}$ : tamarind pulp 100\%, $\mathrm{T}_{2}$ : tamarind pulp 90\%+mango pulp10\%, $\mathrm{T}_{3}$ : tamarind pulp 80\%+mango pulp $20 \%, \mathrm{~T}_{4}$ : tamarind pulp 70\%+mango pulp 30\%, $\mathrm{T}_{5}$ : tamarind pulp 60\%+mango pulp 40\%, $\mathrm{T}_{6}$ : tamarind pulp $50 \%+$ mango pulp $50 \%$. * significant at $1 \%$ level, NS- non significant.

Table.3 Effect of storage period on acidity (\%) in tamarind jam at room temperature

\begin{tabular}{|c|c|c|c|c|c|}
\hline & \multicolumn{5}{|c|}{ Acidity (\%) } \\
\hline TREATMENTS & $\mathbf{0}$ & 30 & 60 & 90 & Mean \\
\hline $\mathrm{T}_{1}$ & 0.653 & 0.653 & 0.651 & 0.647 & 0.651 \\
\hline $\mathrm{T}_{2}$ & 0.693 & 0.693 & 0.691 & 0.687 & 0.691 \\
\hline $\mathrm{T}_{3}$ & 0.724 & 0.724 & 0.722 & 0.719 & 0.722 \\
\hline $\mathrm{T}_{4}$ & 0.754 & 0.754 & 0.751 & 0.749 & 0.752 \\
\hline $\mathrm{T}_{5}$ & 0.783 & 0.783 & 0.781 & 0.776 & 0.780 \\
\hline $\mathrm{T}_{6}$ & 0.822 & 0.738 & 0.820 & 0.817 & 0.820 \\
\hline \multirow[t]{2}{*}{ Mean } & 0.738 & 0.738 & 0.737 & 0.736 & \\
\hline & & $F$ value & SEd \pm & CD at $5 \%$ & \\
\hline Treatments $\left(\mathrm{F}_{1}\right)$ & & $* *$ & 0.0011 & 0.0021 & \\
\hline Periods $\left(\mathbf{F}_{2}\right)$ & & NS & 0.007 & NS & \\
\hline $\mathbf{F}_{1} * \mathbf{F}_{2}$ interaction & & NS & 0.0018 & NS & \\
\hline
\end{tabular}

Where, $\mathrm{T}_{1}$ : tamarind pulp 100\%, $\mathrm{T}_{2}$ : tamarind pulp 90\%+mango pulp10\%, $\mathrm{T}_{3}$ : tamarind pulp 80\%+mango pulp $20 \%, \mathrm{~T}_{4}$ : tamarind pulp $70 \%+$ mango pulp 30\%, $\mathrm{T}_{5}$ : tamarind pulp $60 \%+$ mango pulp $40 \%$, $\mathrm{T}_{6}$ : tamarind pulp $50 \%+$ mango pulp $50 \%$. * * significant at $1 \%$ level, NS- non significant. 
Table.4 Effect of storage period on reducing sugars in tamarind jam at room temperature

\begin{tabular}{|c|c|c|c|c|c|}
\hline \multirow[b]{2}{*}{ TREATMENTS } & \multicolumn{5}{|c|}{ Reducing sugars (\%) } \\
\hline & 0 & 30 & 60 & 90 & Mean \\
\hline $\mathrm{T}_{1}$ & 32.130 & 32.131 & 33.280 & 35.180 & 32.180 \\
\hline $\mathrm{T}_{2}$ & 33.961 & 33.961 & 34.850 & 36.240 & 33.753 \\
\hline $\mathrm{T}_{3}$ & 35.229 & 35.230 & 35.961 & 38.320 & 35.435 \\
\hline $\mathrm{T}_{4}$ & 37.150 & 37.150 & 38.341 & 40.150 & 38.198 \\
\hline $\mathrm{T}_{5}$ & 38.761 & 38.761 & 39.560 & 41.230 & 39.578 \\
\hline $\mathrm{T}_{6}$ & 40.219 & 40.219 & 41.340 & 43.560 & 41.335 \\
\hline Mean & 36.241 & 36.242 & 37.388 & 38.796 & \\
\hline & & F value & SEd \pm & CD at $5 \%$ & \\
\hline Treatments $\left(F_{1}\right)$ & & $* *$ & 0.5607 & 0.1230 & \\
\hline Periods $\left(\mathbf{F}_{2}\right)$ & & $* *$ & 0.3964 & 0.7941 & \\
\hline $\mathbf{F}_{1}{ }^{*} \mathbf{F}_{2}$ Interaction & & $* *$ & 0.9711 & 1.9451 & \\
\hline
\end{tabular}

Where, $\mathrm{T}_{1}$ : tamarind pulp $100 \%, \mathrm{~T}_{2}$ : tamarind pulp $90 \%+$ mango pulp $10 \%, \mathrm{~T}_{3}$ : tamarind pulp $80 \%+$ mango pulp $20 \%, \mathrm{~T}_{4}$ : tamarind pulp $70 \%+$ mango pulp $30 \%, \mathrm{~T}_{5}$ : tamarind pulp $60 \%+$ mango pulp $40 \%$, $\mathrm{T}_{6}$ : tamarind pulp $50 \%+$ mango pulp $50 \%$. * * significant at $1 \%$ level, NS- non significant.

Table.5 Effect of storage period on total sugars (\%) in tamarind jam at room temperature

\begin{tabular}{|c|c|c|c|c|c|}
\hline & \multicolumn{5}{|c|}{ Total sugars (\%) } \\
\hline TREATMENTS & $\mathbf{0}$ & 30 & 60 & 90 & Mean \\
\hline $\mathrm{T}_{1}$ & 51.390 & 51.390 & 51.480 & 51.322 & 51.396 \\
\hline $\mathrm{T}_{2}$ & 52.548 & 52.548 & 52.952 & 52.786 & 52.708 \\
\hline $\mathrm{T}_{3}$ & 54.673 & 54.672 & 54.945 & 54.851 & 54.785 \\
\hline $\mathrm{T}_{4}$ & 57.830 & 57.830 & 57.958 & 57.853 & 57.868 \\
\hline $\mathrm{T}_{5}$ & 59.798 & 59.798 & 59.852 & 59.629 & 59.768 \\
\hline $\mathrm{T}_{6}$ & 62.823 & 62.822 & 62.986 & 62.875 & 62.876 \\
\hline Mean & 56.560 & 56.560 & 56.595 & 56.552 & \\
\hline & & F value & SEd \pm & CD at $5 \%$ & \\
\hline Treatments $\left(F_{1}\right)$ & & $* *$ & 0.0658 & 0.1334 & \\
\hline $\operatorname{Periods}\left(\mathbf{F}_{2}\right)$ & & NS & 0.0465 & NS & \\
\hline $\mathrm{F}_{1} * \mathrm{~F}_{2}$ INTERACTION & & NS & 0.1139 & NS & \\
\hline
\end{tabular}

Where, $\mathrm{T}_{1}$ : tamarind pulp $100 \%, \mathrm{~T}_{2}$ : tamarind pulp $90 \%+$ mango pulp10\%, $\mathrm{T}_{3}$ : tamarind pulp $80 \%+$ mango pulp 20\%, $\mathrm{T}_{4}$ : tamarind pulp 70\%+mango pulp 30\%, $\mathrm{T}_{5}$ : tamarind pulp 60\%+mango pulp 40\%, $\mathrm{T}_{6}$ : tamarind pulp $50 \%+$ mango pulp 50\%.** significant at $1 \%$ level, NS- non significant.

Table.6 Effect of storage period on microbial load (colony forming units/gm) in tamarind jam at room temperature

\begin{tabular}{|c|c|c|c|c|c|c|c|c|}
\hline \multirow{3}{*}{ TREATMENTS } & \multicolumn{8}{|c|}{ Microbial load(colony forming units/gm) } \\
\hline & \multicolumn{2}{|c|}{0 Days } & \multicolumn{2}{|c|}{30 Days } & \multicolumn{2}{|c|}{60 Days } & \multicolumn{2}{|c|}{90 Days } \\
\hline & Bacteria & Y\& M & Bacteria & Y\& M & Bacteria & Y\& M & Bacteria & Y\& M \\
\hline $\mathrm{T}_{1}$ & - & - & - & - & - & - & $4 \times 10^{1}$ & $5 \times 10^{1}$ \\
\hline $\mathrm{T}_{2}$ & - & - & - & - & - & - & $4 \times 10^{1}$ & $4 \times 10^{1}$ \\
\hline $\mathrm{T}_{3}$ & - & - & - & - & - & - & $3 \times 10^{1}$ & $3 \times 10^{1}$ \\
\hline $\mathrm{T}_{4}$ & - & - & - & - & - & - & $3 \times 10^{1}$ & $2 \times 10^{1}$ \\
\hline $\mathrm{T}_{5}$ & - & - & - & - & - & - & $2 \times 10^{1}$ & $1 \times 10^{1}$ \\
\hline $\mathrm{T}_{6}$ & - & - & - & - & - & - & $2 \times 10^{1}$ & $2 \times 10^{1}$ \\
\hline
\end{tabular}

Where, $\mathrm{T}_{1}$ : tamarind pulp $100 \%, \mathrm{~T}_{2}$ : tamarind pulp $90 \%+$ mango pulp10\%, $\mathrm{T}_{3}$ : tamarind pulp $80 \%+$ mango pulp $20 \%, \mathrm{~T}_{4}$ : tamarind pulp $70 \%+$ mango pulp $30 \%, \mathrm{~T}_{5}$ : tamarind pulp $60 \%+$ mango pulp $40 \%$, $\mathrm{T}_{6}$ : tamarind pulp $50 \%+$ mango pulp $50 \%$. * * significant at $1 \%$ level, NS- non significant. 
Fig.1 Flow -chart for extraction of tamarind pulp

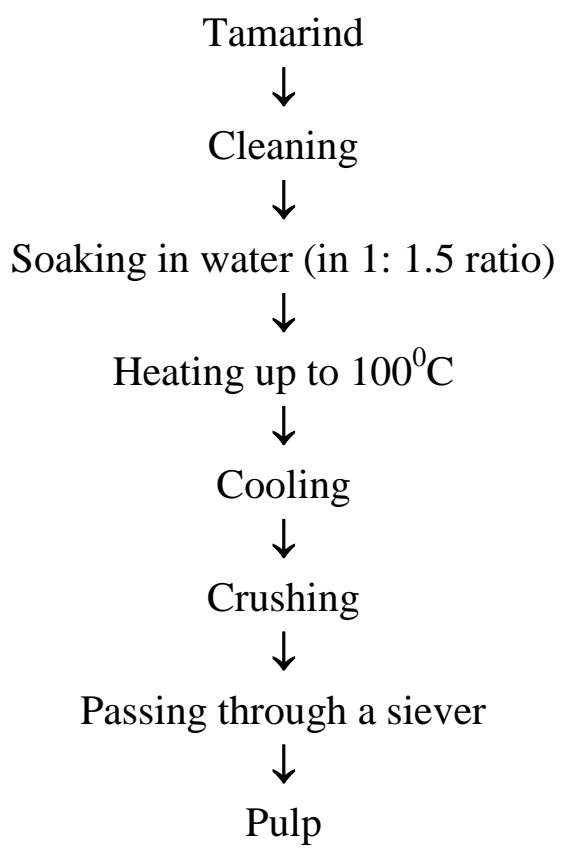

Fig.2 Flow- chart for preparation of tamarind jam

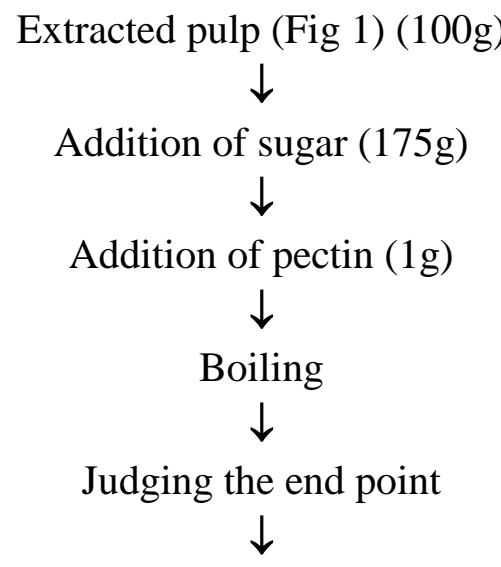

Filling while hot into sterilized bottles

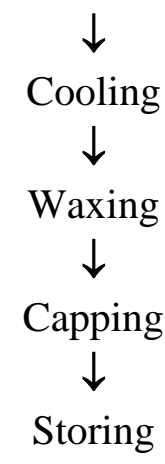


Fig.3 Effect of storage period on overall acceptability in tamarind jam at room temperature

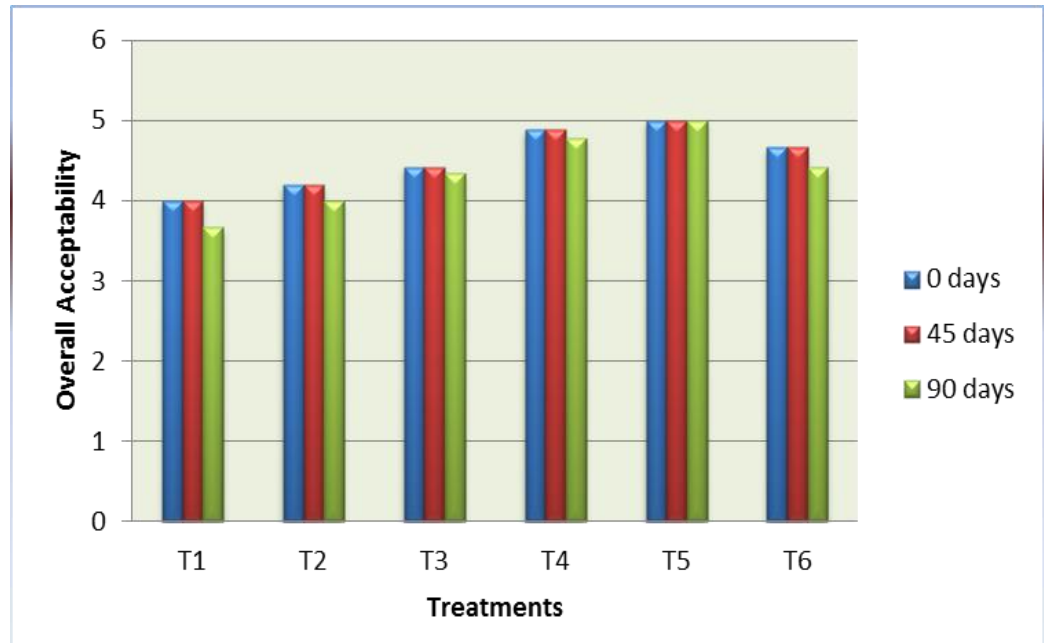

Where, $\mathrm{T}_{1}$ : tamarind pulp $100 \%, \mathrm{~T}_{2}$ : tamarind pulp $90 \%+$ mango pulp10\%, $\mathrm{T}_{3}$ : tamarind pulp $80 \%+$ mango pulp $20 \%, \mathrm{~T}_{4}$ : tamarind pulp 70\%+mango pulp 30\%, $\mathrm{T}_{5}$ : tamarind pulp 60\%+mango pulp 40\%, $\mathrm{T}_{6}$ : tamarind pulp $50 \%+$ mango pulp $50 \%$.

Fig.4 Tamarind jam by blending with mango pulp

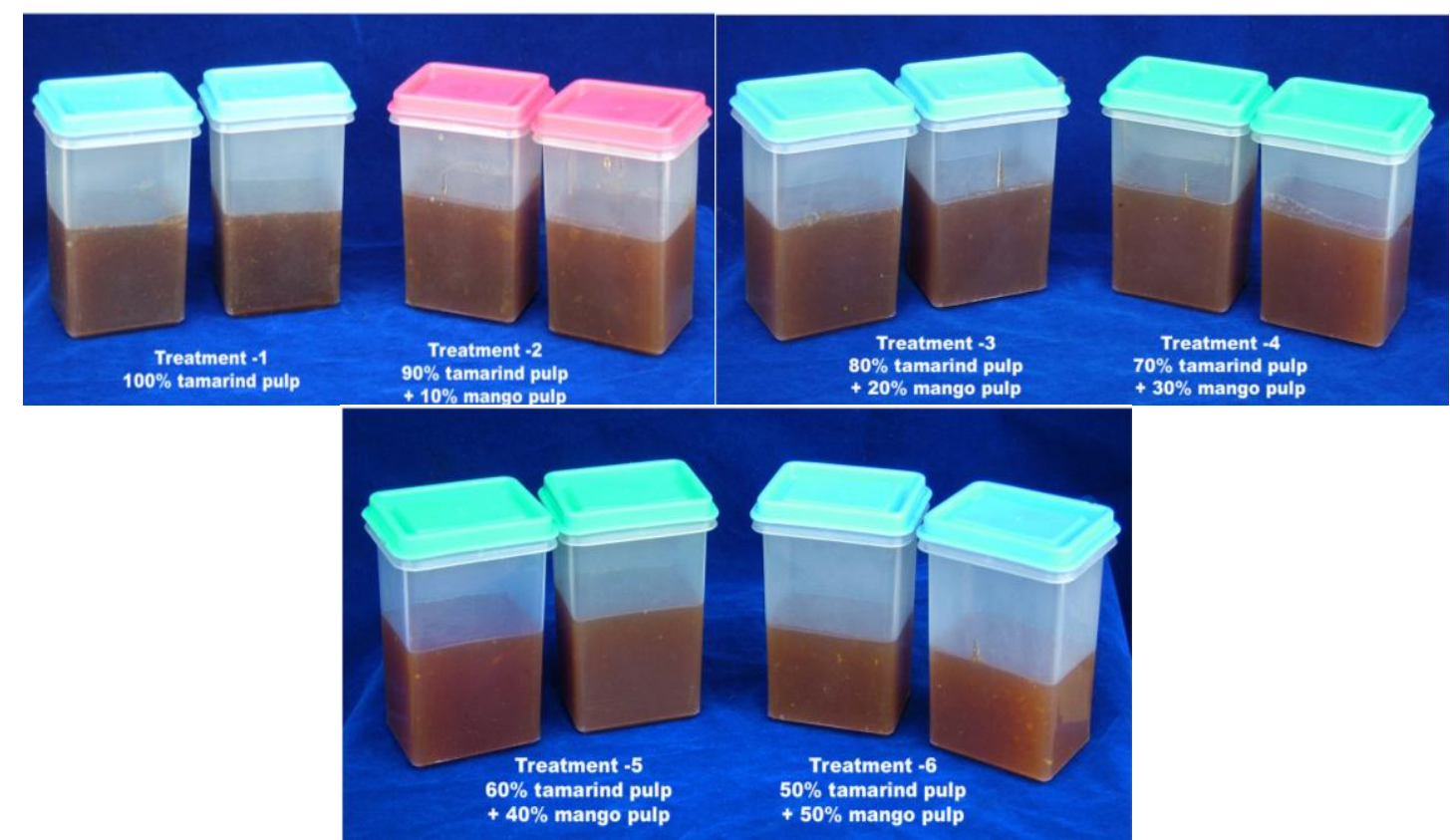

Where, $\mathrm{T}_{1}$ : tamarind pulp 100\%, $\mathrm{T}_{2}$ : tamarind pulp 90\%+mango pulp10\%, T3: tamarind pulp 80\%+mango pulp $20 \%, \mathrm{~T}_{4}$ : tamarind pulp 70\%+mango pulp 30\%, $\mathrm{T}_{5}$ : tamarind pulp 60\%+mango pulp 40\%, $\mathrm{T}_{6}$ : tamarind pulp $50 \%+$ mango pulp 50\%.

Among treatments, significant changes were found in acidity, which might be due to initial differences in acidity maintained during processing.

\section{Reducing sugars (\%)}

Reducing sugars were found to be increased significantly (Table 4) throughout the storage 
period. The significant increase in reducing sugars may be due to inversion of nonreducing to reducing sugars (Tripathi et al., 1988). Similar findings were reported by Shah and Bhatia (1983), Koli et al., (2004) and Kannan and susheela (2001).

\section{Total sugars (\%)}

During storage of tamarind jam, there was practically no change in total sugar content (Table 5) at room temperature upto three months of storage. Similar findings were observed by Ghulam Hassan Shah and Bhatia (1983) in culled apple products. There was a slight increase in total sugars at 60 days of storage, which might be due to increased degree of inversion of sugar on account of higher fixed acidity. Similar findings were reported by Tripathi et al., (1988) in amla jam. At 90 days of storage, a slight decline in total sugars was observed, which might be due to significant increase in reducing sugars. Thus, at the expense of non-reducing sugars, reducing sugars might have increased. This finding was in conformity with the results of Kannan and Susheela Thirumaran (2001) in jamun fruit products.

\section{Sensory evaluation}

All the products were evaluated for sensory attributes (Fig. 3) by a panel of 10 judges for their appearance, colour, consistency, flavour, taste and overall acceptability. A maximum score of 5 was taken as a standard for considering the quality of the products. Of all the treatments, $\mathrm{T}_{5}$ was found to be excellent for all the sensory parameters, at all storage intervals. All the treatments were found acceptable, $\mathrm{T}_{5}$ being highly acceptable. All the samples retained their characteristic tamarind taste and aroma, consistency and overall acceptability throughout the period of storage. The jam samples also retained its normal colour during entire storage period.
Significant decrease was not found in tamarind jam after 90days of storage. Similar trend was observed by Jadhav et al., (2004) in karonda products.

\section{Microbial Load}

A slight increase in microbial load was observed in all the samples during the storage period. However, the increase in microbial growth (Table 6) was within the permissible limit. Application of heat during processing irrespective of holding time reduced the microbial load. Preservative action of sugar also might have resulted in lower microbial load (Srivastava and Kumar, 2002). However, there was negligible growth of yeast and mold in the samples. The findings are in conformity with earlier workers (Kannan and Susheela Thirumaran, 2001).

The overall acceptability was the highest in the jam prepared with $60 \%$ tamarind pulp + $40 \%$ mango pulp $\left(\mathrm{T}_{5}\right)$, stored without any deterioration in physicochemical, sensory quality and microbial count and are consumer acceptable up to 3 months of storage as per the study. Profit estimated for $1 \mathrm{~kg}$ of the tamarind jam was 25.00 when compared with locally available jam. Hence, it can be concluded that blending with mango pulp can bring value addition to tamarind.

\section{References}

Duke JA 1981 Handbook of Legumes of world Economic Important Plenum press, New York, PP 228-230.

Garande VK and Joshi GD 1995 Storage of Jamun Fruit products. Asian food journal 10(2): 54-56.

Jadhav SB Joshi GD and Garande VK 2004 Studies on Preparation and storage of karonda (Carissa carandas. Linn.) fruit products. Beverage and Food World 30(4): 46-47. 
Jain SP, Tripathi VK, Ram HB and Surjeet Singh 1986 Effect of storage conditions on storage life of some important squashes part II. Indian Food Packer 40(2): 36-41.

Kannan S and Thirumaran SA 2001 Studies on storage life of jamun products. Indian Food packer 55(1-6): 125-127.

Koli SA, Kolekar TT, Kute LS and chavan JK 2004 Preparation and storage of sapota jam. Beverage and Food World: 2021.

Multi-Purpose uses of tamarind www.tamarind manual htm.

Salvi M 19991 studies on processing qualities of mango (Mangifera indica), cashew (Anacardim accidentale L) and karonda (Carissa carandas L) fruits and some aspects of blending and storage of their products M.Sc., (Agri.) thesis Submitted to Dr. BS Konkan Krishi Vidyapeeth, Dapoi, Dist., Ratnagiri, and MS.

Shah and Bhatia BS 1983 Studies on the processing culled apples. Journal of Food Science and Technology 42(1): 101-103.

Singh IJ, Singh HK and Chopra CS 2004 studies on storage stability of Barhal Artocarpus lakoocha Rax.b) products. Beverage and Food World: 29-30.

Srivastava and Sanjeev K 2002 fruits and vegetable preservation and principles and practices. International book distribution company Lucknow,

Tripathi VK, MB Singh and Surjeet Singh 1988. Studies on comparative compositional charges in different preserved products of Amla Var. Banarasi Indian Food Packer: 60-66.

\section{How to cite this article:}

Kiranmai, E., A. Suneetha and Nikita Sethi. 2017. Preparation of Tamarind Jam Blended with Mango. Int.J.Curr.Microbiol.App.Sci. 6(12): 3365-3373. doi: https://doi.org/10.20546/ijcmas.2017.612.392 